\title{
JUURNAL_RU
}

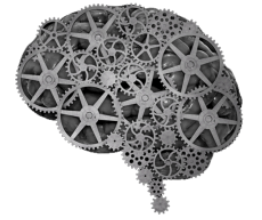

COMPANY GROUP "INTELLEKT"

Иванов В.Е. $A O$ «НИИ ТП»

Москва, Россия

doi: 10.18411/lj2016-5-4-04

\section{Результаты космической деятельности в сегменте Д33 за 2014 год}

По информации с сайта ecoruspace.me в 2014 году на околоземные орбиты были запущены 46спутников. Это гражданские, коммерческие и военныекосмические аппараты (КА) дистанционного зондирования Земли(ДЗ3), принадлежащие 13 странам. Оснащенные оптико-электронной и (или) радиолокационной аппаратурой, позволяющей получать изображения Земли с пространственным разрешением от низкого (1-4 км) до сверхвысокого (более $1 \mathrm{M})$.

Как и в предыдущий год, лидерами в производстве КА, атакжена рынке геопространственной информации, остаются такие страны как США, члены ЕС, Китай, Япония.

Первенство по запускам спутников остается за Китаем - 16 КА ДЗ3. Из $\begin{array}{lllllllll}\text { них } & 7 & \text { военных } & \text { и } & 9 & \text { гражданских } & \text { (в } & \text { том числе } & \text { научных }\end{array}$ гидрометеорологических)спутников. Япония - 9 гражданских КА ДЗ3, разработанных для государственных нужд в области картографии и гидрометеорологии. США в 2014 запустили 8 КА ДЗ3: 4 военных космических аппарата, 3 гражданских и 1 коммерческий спутник. В рамках программы Copernicus, Европейским космическим агентством был запущен спутник Sentinel-1A, обеспечивающий мониторинг покрытых льдом арктических морей. Выведенный на орбитуSPOT 7 коммерческий спутник, созданный европейской аэрокосмической компании EADS Astrium.B 2014 году РФ вывела 
на орбиты2гражданских и 1 военный спутники дистанционного зондирования.Странамиоператорами оставшихся 8 спутников запущенных в 2014 году: Израиль, Испания, Казахстан, Польша, Сингапур, Египет, Южная Африка.

Из 46 выведенных на орбиты спутников только 2 спутникакоммерческие, остальные изготовлены полностью за счет государственных средств.Таким образом, в 2014 году развитие рынка услуг ДЗ3 зависела от государственного финансирования.

На сегодняшний день во всем мире наблюдается тенденция стремительного прогресса в области развития и использования спутников ДЗ3 как военного, так и гражданского назначения. Число стран, участвующих в непосредственной реализации тех или иных проектов связанных со спутниками ДЗ3, по данным ОАО РКС представлен в таблице 1.

Таблийа 1.

\begin{tabular}{|c|c|c|}
\hline Страны & $\begin{array}{c}\text { Общее количество } \\
\text { спутников, ед. }\end{array}$ & $\begin{array}{c}\text { Доля рынка данных и } \\
\text { продуктов Д33, \% }\end{array}$ \\
\hline США & 36 & 61 \\
\hline Китай & 28 & 0,3 \\
\hline Индия & 14 & 1,5 \\
\hline Германия & 13 & 3 \\
\hline Япония & 9 & 0,5 \\
\hline Франция & 6 & 18 \\
\hline Израиль & 6 & 3 \\
\hline Россия & 5 & 0,2 \\
\hline Италия & 4 & 4 \\
\hline Канада & 2 & 6 \\
\hline Прочие & - & 2,5 \\
\hline
\end{tabular}

Сравнивая, результаты космической деятельности в сегменте Д33 можно сказать о лидирующей позиции США над остальными странами мира по количеству действующих на орбите КА. Китай в 2014 г. занимал второе место в мире по количеству функционирующих спутников Земли (в 2013 г. Китай занимал третье место).Складывается положительная тенденция развития китайской космонавтики под влияниемфинансовых ресурсов и политической воли. К сожалению, Россия, по количеству и качеству космических аппаратов Россия уступает и Китаю, и Индии, не говоря уже о США. 


\section{Литература:}

1. http://www.ecoruspace.me;

2. http://www.russianspacesystems.ru 